\title{
SCIENTIFIC HORIZONS
}

Journal homepage: https://sciencehorizon.com.ua

Scientific Horizons, 24(8), 56-65

UDC 633.2/.3:636.085.2:631.5

DOI: $10.48077 /$ scihor.24(8).2021.56-65

\section{Dynamics of the Species Composition of Phytocenoses of Floodplain Mountain Meadows of the Carpathians Subject to Superficial Improvement}

\author{
Volodymyr Kurhak ${ }^{1 *}$, Uliana Karbivska², Nadiia Asanishvili ${ }^{1}$, \\ Sergiy Slyusar ${ }^{1}$, Mykhailo Ptashnik ${ }^{1}$
}

${ }^{1}$ NSC "Institute of Agriculture of the National Academy of Agrarian Science of Ukraine"

08162, 2-b Mashynobudivnykiv Str., Chabany, Kyiv region, Ukraine

${ }^{2}$ Vasyl Stefanyk Precarpathians National University

76018, 57 Shevchenko Str., Ivano-Frankivsk, Ukraine

\section{Article's History:}

Received: 26.08.2021

Revised: 25.09.2021

Accepted: 28.10.2021

\section{Suggested Citation:}

Kurhak, V., Karbivska, U., Asanishvili, N., Slyusar, S., \& Ptashnik, M. (2021). Dynamics of the species composition of phytocenoses of Floodplain Mountain meadows of the Carpathians subject to superficial improvement. Scientific Horizons, 24(8), 56-65.
Abstract. The conducted research of various authors has developed a number of measures for surface improvement of meadowland in various soil and climatic conditions. However, studies on the influence of such surface improvement measures as the use of organic and mineral fertilizers and sowing of perennial grasses and legumes in the sod on the dynamics of the species composition of Floodplain Mountain meadows of the Carpathians have not yet been conducted, which confirms the relevance of this study. The article presents the results of three-year studies conducted during 20172019 in the peasant farm of V.F. Martyshchuk (the Verkhovinsky District of the Ivano-Frankivsk region) to study the features of transformation of the species composition of natural phytocenoses of floodplain Meadows of the Black Cheremosh river of the mountain and forest belt of the Carpathians under the influence of their surface improvement with the use of organic and mineral fertilizers and sowing of a cereal mixture for haymaking use and Tribolium repens L. for multipurpose use. It was found that floodplain Meadow phytocenoses were mainly cereals and mixed grasses with a share of wild cereals of $57-58 \%$ (up to 15 of them \% Festuca rubra L. s. str. and 5-6\% of low-value ones in feed terms Calamagrostis arundinaceae (L.) Roth and Deschampsia caespitosa (L.) Beauv.), mixed grasses - 35-38\% and unseeded Fabaceae $5-7 \%$. When applying a set of measures for surface improvement of cereals and mixed grasses, low productive (within 1.95-2.15 t/ha of dry weight) floodplain mountain meadowlands, their species composition improved. For making $\mathrm{P}_{30} \mathrm{~K}_{60}$ the content of wild plants increased by $2-5 \%$ Fabaceae, and $\mathrm{N}_{60} \mathrm{P}_{30} \mathrm{~K}_{60}$ - by $9-10 \%$ unseeded Poaceae. For haymaking use, Poaceae with Phleum pratense L. and Festuca pratensis Huds. against the background of making $\mathrm{N}_{60} \mathrm{P}_{30} \mathrm{~K}_{60}$ for sowing a mixture in the sod in the spring, their share increased to $74 \%$, and for multi-year use and sowing Trifolium repens $\mathrm{L}$. against the background of making $\mathrm{P}_{30} \mathrm{~K}_{60}$ the quantity of Fabaceae increased to $44 \%$ or by $32 \%$. The highest floral saturation (43 species from 19 families and $93-98 \%$ from perennials) was observed in variants without fertilization and with the introduction of $\mathrm{P}_{30} \mathrm{~K}_{60}$ for multi-year use, which is 4-14 species more compared to haymaking use, or with the introduction of $\mathrm{N}_{60} \mathrm{P}_{30} \mathrm{~K}_{60}$ and or with sowing a mixture of cereals on the background of $\mathrm{N}_{60} \mathrm{P}_{30} \mathrm{~K}_{60}$ for haymaking use, or sowing Trifolium repens L. against the background of $\mathrm{P}_{30} \mathrm{~K}_{60}$ for multipurpose use

Keywords: legumes, cereals, species composition, meadow phytocenosis, mixed grasses, floral saturation 


\section{INTRODUCTION}

One of the most important ways to improve meadowland is to improve its surface. Among the measures of superficial improvement of meadow grass stand, which can dramatically affect its species composition when caring for it, there is fertilization and sowing of herbs. Fertilizers can be used effectively on all types of meadowland. Nevertheless, first, they are highly effective on sufficiently moistened land (floodplain and low-lying Meadows, normal land and irrigated areas of grasslands), where valuable meadow grasses from the mesophyte group predominate [1-2]. Regular use of fertilizers in optimal doses and ratios that correspond to the nature of the herbage and soil characteristics increases the share of valuable forage species in herbage and creates reliable conditions for maintaining high productivity of meadowland for many years [3-5].

Along with mineral fertilizers, organic fertilizers are used in meadows (manure, including liquid, silt from reservoirs, sapropels, bird droppings, peat, wastewater, green mass of green manure, etc.), primarily on poor low-humus soils, as well as for the purpose of their disposal in Mountain Meadows where there is no arable land $[2 ; 6]$. The response of meadow plants to mineral fertilizers is higher than that of field crops. However, the effectiveness of fertilizing meadow grass is largely determined by the ratio of nutrients. On Poaceae in herbage, a complete mineral fertilizer, then in descending order nitrogen-potash, nitrogen-phosphorus, nitrogen, potassium-phosphorus, potassium and phosphorus [2], provides the greatest return.

Nitrogen fertilizers are more effective in meadows that are better provided with moisture (lowland and floodplain) with a predominance in herbage Poaceae herbs. The highest reaction to the application of phosphorous and potash fertilizers is characterized by Fabaceae herbs that, with regular fertilization, last longer in herbage [7]. Nitrogen fertilizers on legume and cereal herbage, in contrast to Poaceae, little effective [8]. When applying nitrogen fertilizers, as you know, the growth of Poaceae at the same time, conditions of potassium and phosphate starvation are created for Fabaceae and there is a displacement of them from the herbage. If there is insufficient potassium supply, valuable grass species fall out and species that can absorb it from hard-to-reach forms spread [9].

In recent years, the interest of sowing herbs has significantly increased on meadowlands of industrial workers and scientists due to the emergence of new technical opportunities and an energy and environmental crisis in the national economy of Ukraine [2]. It was found that seeding Poaceae in undisturbed Meadow turf, it does not give positive results in conditions of insufficient supply of nitrogen to the soil. Seedlings that are provided with nitrogen due to its fixation by nodule bacteria take root better. Greater positive effect of seeding Fabaceae it is manifested when the soil is sufficiently provided with mobile forms of phosphorus and potassium [10]. For successful sowing, it is necessary to weaken the old coenosis and strengthen the ability of seedlings of sown species to grow rapidly. Better results from this measure are observed in wet growing conditions and in wetter years, in particular in low-lying Meadows than in dry ones [11].

Sowing a legume-cereal mixture in a degenerate Meadow stand quickly improves the species composition of agrocoenoses, reducing the proportion of low-value mixed grasses in feed terms and increasing the productivity of meadowland and feed quality $[12 ; 13]$. A similar effect on the structure of reducing coenoses is produced by sowing a cereal mixture, but mineral nitrogen fertilizers provide the increased and stable productivity of these coenoses over the years. Improves the species composition and accelerates the process of stabilization of Meadow coenoses and sowing seeds of wild grass species, which are collected in meadows adapted to certain conditions with natural, but productivity remains low [14].

In the practice of onion farming, the most promising method of creating legume-cereal herbage is sowing perennials Fabaceae herbs in loosened strips by combined aggregates [15]. It was found that for seed germination and survival of seedlings, appropriate conditions are necessary, which take root better in places with partially disturbed sod, as well as when draining seeds using phosphorous fertilizers and inoculants. The best results are obtained when sowing Fabaceae in a grass stand that has no strong competitors, as well as without the use of nitrogen fertilizers.

The analysis of literature sources on the development and improvement of measures for surface improvement of meadowlands shows that the features of transformation of the species composition of phytocenoses of floodplain mountain meadows of the Carpathians with their surface improvement have not yet been studied. This has become the subject of our research, which is covered in this article.

Research purpose it consists in establishing the features of transformation of the species composition of phytocenoses of floodplain Meadows of the mountain and forest belt of the Carpathians with their superficial improvement.

\section{MATERIALS AND METHODS}

Experimental studies on the peculiarities of transformation of the species composition of phytocenoses of Floodplain Meadows of the mountain and forest belt of the Carpathians with their surface improvement were carried out during 2017-2019 in the peasant economy of V.F. Martyshchuk (P. Krasnik Verkhovinsky district, Ivano-Frankivsk region) in the floodplain of the Black Cheremosh river. The soil cover of the experimental site consists of sod-brown-earth shallow underdeveloped carbonate light loamy on alluvium calcites, middle-stony 
on the modern alluvium, which is covered with pebbles from a depth of $0.5-1.0 \mathrm{~m}$. The $0-20-\mathrm{cm}$ layer of this soil contains humus $-2.6 \%$, alkaline hydrolyzed nitrogen $8.4 \mathrm{mg} / \mathrm{kg}$, mobile phosphorus - $4.3 \mathrm{mg} / \mathrm{kg}$, exchange potassium $-7.8 \mathrm{mg} / \mathrm{kg}$ with $\mathrm{PH}$ Sol. -5.0 and ecological and agrochemical score- 16 .

The study was conducted according to generally accepted methods in feed production and onion farming [16]. The size of sown plots is $10 \mathrm{~m}^{2}$, accounting $-8 \mathrm{~m}^{2}$. The experiment is repeated four times. The experiment scheme included the following options and factors (table. 1): improvement factor: 1) no improvement, 2) $P_{30} K_{60}$, 3) $N_{60} P_{30} K_{60}$, 4) $15 \mathrm{t} /$ ha of manure, $P_{30} K_{60}+$ seeding Trifolium repens L. $6 \mathrm{~kg} / \mathrm{ha}$ for multipurpose use and 5) $\mathrm{N}_{60} \mathrm{P}_{30} \mathrm{~K}_{60}+$ seeding the mixture of Poaceae (Phleum pratense L., $6 \mathrm{~kg} /$ ha + Festuca pratensis Huds., $10 \mathrm{~kg} / \mathrm{ha}$ ). Factor usage mode: 1) haymaking with 2 slopes and 2) multi-slope (imitation of pasture use).

Mineral fertilizers, in doses according to the experiment scheme, in particular, nitrogen in the form of ammonium nitrate, phosphorous - granular superphosphate and potash - kalimagnesia, as well as litter manure, in doses according to the experiment scheme, were applied annually in one period in the spring superficially after snowmelt. Sowing of a mixture of cereals and creeping Clover according to the experiment scheme was carried out once in the spring superficially when laying the experiment in 2017. Mowing of grasses for haymaking use in the first mowing was carried out in the flowering phase of the dominant components of the grass stand, and for multi-mowing (imitation of pasture) and after grass for haymaking use - the height of the grass stand is $15-20 \mathrm{~cm}$.

The species composition of the meadow phytocenosis on the experimental site was studied under the influence of measures for its surface improvement by geobotanical description of grass stands before considering the harvest according to DSTU 4687:2007 [17]. The definition of Meadow plant species and their families was carried out in accordance with the modern nomenclature of taxa [18].

\section{RESULTS AND DISCUSSION}

Studies conducted by various authors have established that surface improvement, in particular the introduction of organic and mineral fertilizers and sowing of cereals and legumes of perennial grasses in the sod, has a positive effect on the species composition of Meadow phytocenoses, which in turn has a positive effect on the productivity and chemical composition and nutritional value of feed $[2 ; 19 ; 20]$. In particular, with the introduction of nitrogen fertilizers, growth and development improves and the number of long-term fertilizers increases Poaceae herbs and the number of perennials decreases Fabaceae herbs and mixed grasses in Meadow phytocenoses. At the same time, their floral saturation decreases. The introduction of phosphorous and potash fertilizers, especially in years favorable for precipitation, leads to an increase in the meadow phytocenosis of perennial plants. Fabaceae and reducing the number of Poaceae.

Sowing of cultivated species adapted to certain ecological conditions of the growing place, perennial Fabaceae without applying nitrogen fertilizers or Poaceae by applying these fertilizers, it increases the share of sown species in Meadow phytocenoses. Sowing seeds of wild species on degraded Meadow herbage adapted to certain ecological conditions improves the species composition and accelerates the process of its stabilization [2].

The results of our research presented in the article on the influence of surface improvement measures for floodplain meadowlands with natural herbage of the Black Cheremosh River in the Carpathian Mountain and forest belt on their botanical feed composition are described below. The original herbage before laying the experiment was cereal-mixed with the content of wild plants Poaceae 53-54\%, mixed grasses - 39-42\% and unseeded Fabaceae 4-8\%, which is clearly visible in Figure 1 in the version without fertilizers.

For both haymaking and multi-mowing use in the fertilizer-free version on average for 2017-2019 studies compared to the first year, the ratio between Poaceae and mixed grasses did not change much, although there was a tendency to increase Poaceae and reduction of mixed grasses (Table 1 , Fig. 1). For $\mathrm{P}_{30} \mathrm{~K}_{60}$, there was an increase in the content of wild perennial Fabaceae plants for haymaking use by $2 \%$, and for multicut - by $5 \%$.

For $\mathrm{N}_{60} \mathrm{P}_{30} \mathrm{~K}_{60}$ compared to $\mathrm{P}_{30} \mathrm{~K}_{60}$ during haymaking use, an increase was observed in unseeded crops of Poaceae by $9 \%$ while the content was reduced of Fabaceae by $5 \%$ and of mixed grasses by $6 \%$. In this case, the multi-year use of cereals increased by $10 \%$, and legumes and various grasses decreased by 7 and $8 \%$, respectively.

When applying manure in comparison with the option without fertilizers, the changes between these botanical groups were similar to the changes that were observed under the action of applying $\mathrm{N}_{60} \mathrm{P}_{30} \mathrm{~K}_{60}$ compared to making a $\mathrm{P}_{30} \mathrm{~K}_{60}$, but less pronounced (Table 1 ). When applying manure in comparison with the option without fertilizers for haymaking use, an increase was observed in the share of unseeded crops of Poaceae by $7 \%$ when the content was reduced of Fabaceae by $2 \%$ and of mixed grasses by $5 \%$. For multipurpose use, Poaceae increased by $5 \%$ in this case, and Fabaceae and mixed grasses decreased by 1 and 4\%, respectively.

Analysis of the results of sowing a mixture of Poaceae herbs and Phleum pratense L. and Festuca pratensis Huds. in the sod in spring against the background of making $\mathrm{N}_{60} \mathrm{P}_{30} \mathrm{~K}_{60}$ for haymaking use showed that the greatest changes occurred with the Botanical composition of the herbage in this case, according to the average data. Total share Poaceae compared to making $\mathrm{N}_{60} \mathrm{P}_{30} \mathrm{~K}_{60}$ it increased from 67 to $74 \%$ or by $7 \%$, and compared 
to the option without fertilizers - by $17 \%$, and mixed grasses decreased - by 6 and $13 \%$, respectively. As part of the Poaceae Botanical group, the total share of sown grasses increased to $43 \%$, including Phleum pratense L. up to $19 \%$, and Festuca pratensis Huds. - up to $24 \%$. At the same time, the number of unseeded Poaceae crops decreased by $26 \%$ compared to the option with the introduction of $\mathrm{N}_{60} \mathrm{P}_{30} \mathrm{~K}_{60}$ and by $22 \%$ compared to the option without fertilization.

For multi-year use for sowing in the sod in spring against the background of $\mathrm{P}_{30} \mathrm{~K}_{60}$ Trifolium repens $\mathrm{L}$. application according to the data averaged over three years, its share increased by $30 \%$, and the total number of Fabaceae increased from 12 to $44 \%$ or by $32 \%$, and by $37 \%$ compared to the option without fertilization. Simultaneously, the share of Poaceae decreased by 16 and $20 \%$, respectively, and that one of mixed grasses by 11 and $6 \%$, respectively.

Analysis of the results of studies by year showed that in this case, the patterns of changes that occurred with the ratio of botanical groups of grass stands, both for haymaking and multi-mowing use, were mostly similar to the results obtained on average over three years (Fig. 1). For haymaking use in the direction from the $1^{\text {st }}$ to the $3^{\text {rd }}$ year, there was an increase in the total share of grass stands Poaceae and a reduction in the number of mixed grasses by $3-9 \%$. Against the background of making $\mathrm{N}_{60} \mathrm{P}_{30} \mathrm{~K}_{60}$ and for sowing the mixture Poaceae these changes were more significant. Among the sown herbs in the variant with sowing a mixture of cereals for three years there was an increase in the content Phleum pratense L. and reducing the share Festuca pratensis Huds. by $8-13 \%$.

For multi-manual use, the largest share of Poaceae in most options, except for the option with seeding Trifolium repens L., was in the second year of use. At the same time, this year, in these variants, the lowest share of Fabaceae in the herbage (at the level of 3-5\%) was also due to adverse weather conditions, resulted from the lack of moisture. Meanwhile, as in the option with seeding Trifolium repens $L$. in the sod, its share was stable during all three years of research in the herbage at the level of $37-40 \%$.

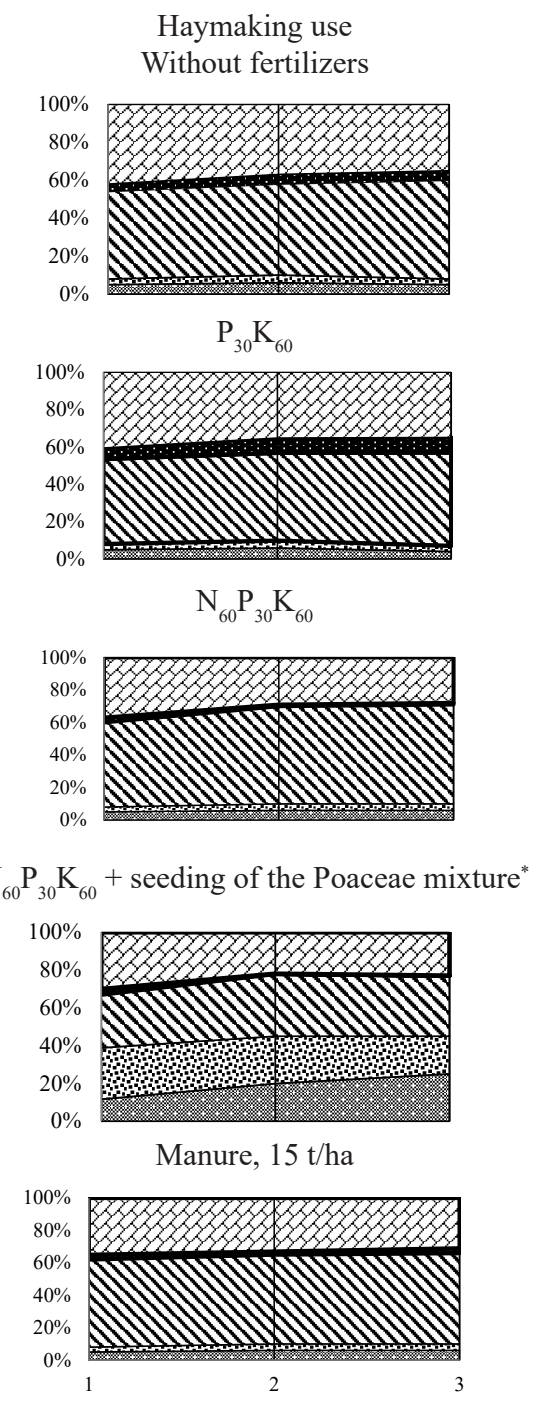

- mixed grasses;

- unseeded Fabaceae; $\$$ - Trifolium repens $\mathrm{L}$.

Multipurpose use Without fertilizers
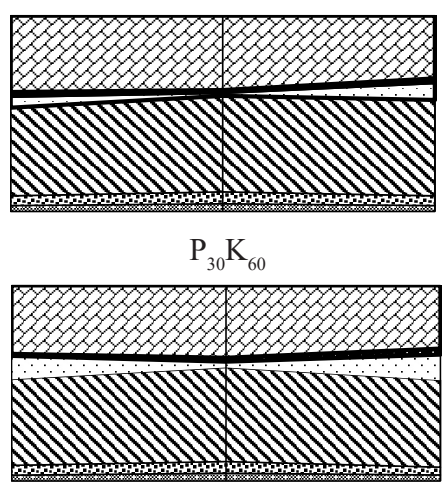

$\mathrm{P}_{30} \mathrm{~K}_{60}+$ seeding Trifolium repens $\mathrm{L}$.

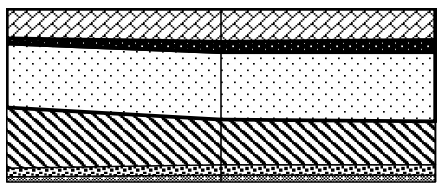

$\mathrm{N}_{60} \mathrm{P}_{30} \mathrm{~K}_{60}$

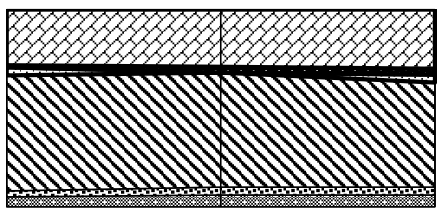

Manure, 15 t/ha

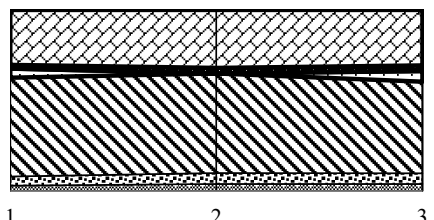

of the grass mixture; $-1^{\text {st }}$ cereal component of the grass mixture

Figure 1. Botanical composition of the grass stand of floodplain mountain meadows depending on surface improvement measures, 2017-2019,\%

Notes: 1, 2, 3 - years of use. *Components of the mixture: 1) Phleum pratense L., $6 \mathrm{~kg} / \mathrm{ha}+2)$ Festuca pratensis Huds., $10 \mathrm{~kg} / \mathrm{ha}$ 
Table 1. Botanical composition of the grass stand of floodplain Meadows depending on surface improvement measures (average for 2017-2019)

\begin{tabular}{|c|c|c|c|c|c|c|c|}
\hline \multirow{3}{*}{$\begin{array}{l}\text { Options for } \\
\text { improvement } \\
\text { measures }\end{array}$} & \multirow{3}{*}{ Total Poaceae } & \multicolumn{3}{|c|}{ Including } & \multirow{3}{*}{$\begin{array}{c}\text { Total } \\
\text { Fabaceae }\end{array}$} & \multirow{3}{*}{$\begin{array}{l}\text { Including } \\
\text { Trifolium } \\
\text { repens L. }\end{array}$} & \multirow{3}{*}{$\begin{array}{l}\text { Miscellaneous } \\
\text { herbs }\end{array}$} \\
\hline & & $\mathrm{By}$ & ents* & Unseeded & & & \\
\hline & & First & Second & & & & \\
\hline \multicolumn{8}{|c|}{ Haymaking use } \\
\hline Without fertilizers & 57 & 5 & 3 & 49 & 5 & - & 38 \\
\hline $\mathrm{P}_{30} \mathrm{~K}_{60}$ & 56 & 5 & 3 & 48 & 7 & - & 37 \\
\hline $\mathrm{N}_{60} \mathrm{P}_{30} \mathrm{~K}_{60}$ & 67 & 6 & 4 & 57 & 2 & - & 31 \\
\hline $\begin{array}{c}\mathrm{N}_{60} \mathrm{P}_{30} \mathrm{~K}_{60}+\text { seeding } \\
\text { of the Poaceae } \\
\text { mixture* }\end{array}$ & 74 & 19 & 24 & 31 & 1 & - & 25 \\
\hline Manure, $15 \mathrm{t} / \mathrm{ha}$ & 64 & 6 & 4 & 54 & 3 & - & 33 \\
\hline \multicolumn{8}{|l|}{$\mathrm{HIP}_{05}, \mathrm{t} / \mathrm{ha}$} \\
\hline \multicolumn{8}{|c|}{ Multipurpose use } \\
\hline Without fertilizers & 58 & 3 & 5 & 50 & 7 & 6 & 35 \\
\hline $\mathrm{P}_{30} \mathrm{~K}_{60}$ & 54 & 3 & 5 & 46 & 12 & 9 & 37 \\
\hline $\begin{array}{l}\mathrm{P}_{30} \mathrm{~K}_{60}+\text { seeding } \\
\text { Trifolium repens } \mathrm{L} \text {. }\end{array}$ & 38 & 4 & 6 & 28 & 44 & 39 & 18 \\
\hline $\mathrm{N}_{60} \mathrm{P}_{30} \mathrm{~K}_{60}$ & 66 & 6 & 4 & 56 & 5 & 3 & 29 \\
\hline Manure, 15 t/ha & 63 & 4 & 6 & 53 & 6 & 4 & 31 \\
\hline $\mathrm{HIP}_{05}, \mathrm{t} / \mathrm{ha}$ & 3 & 1 & 1 & 3 & 2 & 2 & 2 \\
\hline
\end{tabular}

${ }^{*}$ Components of the mixture: 1) Phleum pratense L., $\left.6 \mathrm{~kg} / \mathrm{ha}+2\right)$ Festuca pratensis Huds., $10 \mathrm{~kg} / \mathrm{ha}$

The results of studies on the study of the floral saturation of the meadow natural grass stand of the floodplain in the third year of use, depending on the measures of surface improvement for haymaking and multi-mowing use are shown in Table 2. Their analysis showed that among the improvement measures in the composition of the meadow phytocenosis of the floodplain, the largest number of species (43) was recorded for multi-peak use in variants without fertilization and against the background of $\mathrm{P}_{30} \mathrm{~K}_{60}$, which is 6 more species than for haymaking use.

Table 2. Share of components of meadow grass stand of the floodplain depending on surface improvement measures, \% (3rd 2019 year of use)

\begin{tabular}{|c|c|c|c|c|c|c|c|c|}
\hline \multirow[b]{2}{*}{ Types } & \multicolumn{4}{|c|}{ Haymaking use } & \multicolumn{4}{|c|}{ Multipurpose use } \\
\hline & $\begin{array}{l}\text { Without } \\
\text { fertilizers }\end{array}$ & $P_{30} K_{60}$ & $\mathbf{N}_{60} \mathbf{P}_{30} \mathbf{K}_{60}$ & $\begin{array}{c}\mathrm{N}_{60} \mathrm{P}_{30} \mathrm{~K}_{60}+ \\
\text { seeding of } \\
\text { the Poaceae } \\
\text { mixture }\end{array}$ & $\begin{array}{l}\text { Without } \\
\text { fertilizers }\end{array}$ & $P_{30} K_{60}$ & $\begin{array}{l}\mathrm{P}_{30} \mathrm{~K}_{60}+ \\
\text { seeding } \\
\text { Trifolium } \\
\text { repens L. }\end{array}$ & $\mathbf{N}_{60} \mathbf{P}_{30} \mathbf{K}_{60}$ \\
\hline \multicolumn{9}{|c|}{ Poaceae } \\
\hline Cynosurus cristatus L. & 5 & 5 & 4 & 2 & 3 & 2 & - & 4 \\
\hline Festuca pratensis Huds. & 3 & 3 & 4 & 20 & 5 & 4 & 6 & 4 \\
\hline Festuca ovina L. & 3 & 3 & 3 & - & 8 & 6 & 5 & 8 \\
\hline Festuca rubra L. s. str. & 13 & 13 & 15 & 10 & 15 & 14 & 11 & 18 \\
\hline $\begin{array}{c}\text { Calamagrostis arundinaceae (L.) } \\
\text { Roth }\end{array}$ & 4 & 4 & 6 & 3 & + & + & + & - \\
\hline Holcus mollis L. & 8 & 6 & 7 & 3 & 9 & 7 & 5 & 9 \\
\hline Agrostis gigantea Roth & 3 & 3 & 8 & 7 & + & + & + & - \\
\hline Agrostis canina L. & - & - & - & - & + & 1 & + & 3 \\
\hline Agrostis tenuis Sibth. & 1 & 1 & - & - & + & + & - & - \\
\hline Elytrigia repens (L.) Nevski & 5 & 5 & 7 & 4 & 5 & 5 & - & 5 \\
\hline Phleum pratense L. & 5 & 4 & 6 & 25 & 3 & 3 & 4 & 6 \\
\hline
\end{tabular}


Table 2, Continued

\begin{tabular}{|c|c|c|c|c|c|c|c|c|}
\hline \multirow[b]{2}{*}{ Types } & \multirow[b]{2}{*}{$\begin{array}{l}\text { Without } \\
\text { fertilizers }\end{array}$} & \multicolumn{2}{|c|}{ Haymaking use } & \multirow[b]{2}{*}{$\begin{array}{c}\mathrm{N}_{60} \mathrm{P}_{30} \mathrm{~K}_{60}+ \\
\text { seeding of } \\
\text { the Poaceae } \\
\text { mixture }\end{array}$} & \multirow[b]{2}{*}{$\begin{array}{l}\text { Without } \\
\text { fertilizers }\end{array}$} & \multicolumn{2}{|c|}{ Multipurpose use } & \multirow[b]{2}{*}{$\mathbf{N}_{60} \mathbf{P}_{30} \mathbf{K}_{60}$} \\
\hline & & $\mathbf{P}_{30} \mathrm{~K}_{60}$ & $\mathbf{N}_{60} \mathbf{P}_{30} \mathbf{K}_{60}$ & & & $\mathbf{P}_{30} \mathbf{K}_{60}$ & $\begin{array}{l}\mathrm{P}_{30} \mathrm{~K}_{60}+ \\
\text { seeding } \\
\text { Trifolium } \\
\text { repens L. }\end{array}$ & \\
\hline Poa palustris L. & 7 & 7 & 10 & 3 & 2 & 2 & - & 4 \\
\hline Poa annua L. & + & + & - & - & 3 & 3 & 2 & - \\
\hline Briza media L. & - & - & - & - & + & + & - & - \\
\hline $\begin{array}{c}\text { Deschampsia caespitosa (L.) } \\
\text { Beauv. }\end{array}$ & 4 & 4 & 1 & + & 5 & 4 & 2 & 2 \\
\hline Total types, \% & 60 & 57 & 71 & 74 & 57 & 52 & 35 & 63 \\
\hline Total types, pcs. & 13 & 13 & 11 & 10 & 15 & 15 & 10 & 10 \\
\hline \multicolumn{9}{|c|}{ Fabaceae } \\
\hline Trifolium montanum L. & 4 & 5 & 1 & - & 1 & 2 & 5 & 2 \\
\hline Trifolium pratense L. & 1 & 3 & - & - & 1 & 1 & 2 & 1 \\
\hline Trifolium repens L. & - & - & - & - & 9 & 13 & 40 & 4 \\
\hline Total types, \% & 5 & 8 & 1 & - & 11 & 16 & 47 & 7 \\
\hline Total types, pcs. & 2 & 2 & 1 & - & 3 & 3 & 3 & 3 \\
\hline \multicolumn{9}{|c|}{ Mixed grasses" } \\
\hline Arnica montana $\mathrm{L}$. & 3 & 3 & 3 & + & 3 & 3 & + & 3 \\
\hline Anemone nemorosa $\mathrm{L}$. & + & + & + & + & + & + & + & + \\
\hline Blechnum spicant (L.) Roth & + & + & - & - & + & + & - & - \\
\hline Heracleum spondylium L. & + & + & + & + & + & + & + & + \\
\hline $\begin{array}{c}\text { Capsella bursa-pastoris (L.) } \\
\text { Medik. }\end{array}$ & 4 & 4 & 2 & 3 & 4 & 4 & 3 & 3 \\
\hline Rhinanthus alpinus Baumg. & 5 & 5 & 3 & 3 & 5 & 5 & 3 & 4 \\
\hline Rhinanthus minor L. & + & + & - & - & + & + & - & - \\
\hline Campanula carpatica Jacq. & + & + & + & - & + & + & - & + \\
\hline Ranunculus acris L. & + & + & + & + & + & + & + & + \\
\hline Stellaria media (L.) Vill. & + & + & - & - & + & + & - & - \\
\hline Carum carvi L. & + & + & + & + & + & + & + & + \\
\hline Leucanthemum vulgare Lam. & 4 & 4 & 4 & 4 & 4 & 4 & 4 & 4 \\
\hline $\begin{array}{c}\text { Taraxacum officinale Webb. } \\
\text { ex Wigg }\end{array}$ & 5 & 5 & 5 & 4 & 5 & 5 & 2 & 5 \\
\hline Hieracium viscidulum Tausch & - & - & + & + & + & + & + & + \\
\hline Cirsium arvense (L.) Scop. & - & - & + & + & + & + & + & + \\
\hline Clinopodium vulgare L. & + & + & - & - & - & - & - & - \\
\hline Potentila anserina $\mathrm{L}$. & 3 & 3 & 3 & 3 & 3 & 3 & 3 & 3 \\
\hline Potentila aurea $\mathrm{L}$. & 1 & 1 & 1 & 1 & 1 & 1 & 1 & 1 \\
\hline Potentila argentea $\mathrm{L}$. & 5 & 5 & 5 & 4 & 5 & 5 & 2 & 5 \\
\hline Galium aparine L. & - & - & - & - & + & + & - & - \\
\hline Plantago lanceolata L. & 2 & 2 & 2 & + & 2 & 2 & + & 2 \\
\hline Juncus castaneus Smith & + & + & + & + & + & + & + & + \\
\hline Viola biflora L. & - & - & - & - & + & + & - & - \\
\hline Equisetum sylvaticum L. & + & + & + & - & + & + & - & - \\
\hline Rumex carpaticus Zapal. & + & + & + & 1 & + & + & + & + \\
\hline Total types, \% & 35 & 35 & 28 & 23 & 32 & 32 & 18 & 30 \\
\hline Total types, pcs. & 22 & 22 & 18 & 16 & 25 & 25 & 16 & 19 \\
\hline \multicolumn{9}{|c|}{ Cyperacea } \\
\hline Carex digitate L. & - & - & - & - & + & + & - & + \\
\hline Carex montana L. & - & - & - & - & + & + & - & + \\
\hline Total types, pcs. & 37 & 37 & 30 & 26 & 43 & 43 & 29 & 32 \\
\hline
\end{tabular}

Notes: * - mix components: 1) Phleum pratense L., $6 \mathrm{~kg} / \mathrm{ha}+2)$ Festuca pratensis Huds., $10 \mathrm{~kg} / \mathrm{ha}$; ${ }^{* *}$ - the amount of mixed grasses is given together with Cyperacea

It should be noted that for making $\mathrm{N}_{60} \mathrm{P}_{30} \mathrm{~K}_{60}$ in comparison with the background $\mathrm{P}_{30} \mathrm{~K}_{60}$ the floral saturation of the studied coenosis decreased from 43 to 29 or by 14 species for multi-year use and from 37 to 30 or by
7 species for haymaking use. The lowest floral saturation was in the variants with sowing perennial grasses in the sod. For sowing the mixture of Poaceae herbs on the background of $\mathrm{N}_{60} \mathrm{P}_{30} \mathrm{~K}_{60}$ for haymaking use, the total 
number of species decreased from 30 to 26 or by 4 species, and for sowing Trifolium repens $L$. for multi-year use on the background of $\mathrm{P}_{30} \mathrm{~K}_{60}$ - from 43 to 29 or for 14 types. The floral saturation of the phytocenosis in all variants of surface improvement was higher for multiyear use than for haymaking.

Most of the species (25) were from the Botanical group of mixed grasses together with Cyperacea with the highest share of $32 \%$, also recorded on the same backgrounds and usage mode. Arnica montana L., Capsella bursa-pastoris (L.) Medik., Rhinanthus alpinus Baumg., Leucanthemum vulgare Lam., Taraxacum officinale Webb. ex Wigg, Potentila anserina L., Potentila aurea L., and Potentila argentea L., Rumex carpaticus Zapal were among the mixed grasses, the share of which was the largest, namely in the range of $1-5 \%$. The remaining species listed in Table 2 were found singly. The modes of Use and fertilization did not naturally affect the share of species from the mixed grass group.

In second place on the same fertilizer options in terms of the number of species (15) was the Botanical group Poaceae with a share of $52-57 \%$ against the background of $\mathrm{P}_{30} \mathrm{~K}_{60}$ and multi-level usage mode. Festuca rubra L. s. str. (14-15\%), Holcus mollis L. and Festuca ovina L. (6-9\% each), Deschampsia caespitosa (L.) Beauv., Elytrigia repens (L.) Nevski, Festuca pratensis Huds., Poa palustris L. and Poa annua L., Phleum pratense L., Cynosurus cristatus L. (4-5\% each) occupied the largest share among Poaceae for these options. Calamagrostis arundinaceae (L.) Roth, Agrostis gigantea Roth. were present for haymaking use in the herbage with a share in the range of $3-8 \%$, while for multi-year use they were found mainly singly. On the contrary, Poa annua L. more was in the grass stand for multi-armed use. The total number increased from 10 to $45 \%$ for sowing the mixture of Poaceae herbs with Festuca pratensis Huds. and Phleum pratense $\mathrm{L}$. on the background of $\mathrm{N}_{60} \mathrm{P}_{30} \mathrm{~K}_{60}$.

The lowest number of species (3) was from the Fabaceae group with the highest share (47\%) in the variant with seeding Trifolium repens $\mathrm{L}$. against the background of making $\mathrm{P}_{30} \mathrm{~K}_{60}$ for multipurpose use. Against the background of making $\mathrm{P}_{30} \mathrm{~K}_{60}$ without seeding Trifolium repens $L$., the share of its wild population was $13 \%$. Due to seeding Trifolium repens L., its share increased by $34 \%$ in the $3^{\text {rd }}$ year of use. The share of Trifolium montanum $L$. was more under the haymaking regime than under the multi-towed one.

When analyzing the distribution of components by the life span of the meadow grass stand of the floodplain, it was revealed that regardless of the studied surface improvement options and use modes, among all species, most (24-37) belonged to perennials, with a share of $93-98 \%$ of the total crop weight (Table 3). Regarding surface improvement measures in both modes of use, the largest number of perennials with the largest percentage of the total crop mass was in the version without fertilizers and against the background of $\mathrm{P}_{30} \mathrm{~K}_{60}$, and least of all for sowing seeds Poaceae or Fabaceae grass in the sod. With additional application of nitrogen in a dose of $\mathrm{N}_{60}$ against the background of $\mathrm{P}_{30} \mathrm{~K}_{60}$ the number of perennials decreased, as well as the total number of species. The number of annuals and biennials was insignificant with fluctuations of $1-5$ and 1 species, respectively, with a share of $2-7 \%$ and $0-3 \%$ of the total crop mass.

Table 3. Distribution of meadow grassland components by life expectancy depending on surface improvement measures, $3^{\text {rd }} 2019$ year of use

\begin{tabular}{|c|c|c|c|c|c|c|c|}
\hline \multirow{2}{*}{ Options for improvement measures } & \multicolumn{4}{|c|}{ Number of types, pcs. } & \multicolumn{3}{|c|}{$\%$ Of the total crop weight } \\
\hline & $\odot$ & $\Theta$ & $\mathbf{Y}$ & Together & $\odot$ & $\Theta$ & $\Upsilon$ \\
\hline \multicolumn{8}{|c|}{ Haymaking use } \\
\hline Without fertilizers & 4 & 1 & 32 & 37 & 4 & 1 & 95 \\
\hline $\mathrm{P}_{30} \mathrm{~K}_{60}$ & 4 & 1 & 32 & 37 & 4 & 3 & 93 \\
\hline $\mathrm{N}_{60} \mathrm{P}_{30} \mathrm{~K}_{60}$ & 1 & 1 & 28 & 30 & 2 & - & 98 \\
\hline $\mathrm{N}_{60} \mathrm{P}_{30} \mathrm{~K}_{60}+$ seeding of the Poaceae mixture & 1 & 1 & 24 & 26 & 3 & - & 97 \\
\hline \multicolumn{8}{|l|}{$\mathrm{HIP}_{05}, \mathrm{t} / \mathrm{ha}$} \\
\hline \multicolumn{8}{|c|}{ Multipurpose use } \\
\hline Without fertilizers & 5 & 1 & 37 & 43 & 7 & - & 93 \\
\hline $\mathrm{P}_{30} \mathrm{~K}_{60}$ & 5 & 1 & 37 & 43 & 7 & - & 93 \\
\hline $\mathrm{P}_{30} \mathrm{~K}_{60}+$ seeding Trifolium repens $\mathrm{L}$. & 2 & 1 & 26 & 29 & 5 & - & 95 \\
\hline $\mathrm{N}_{60} \mathrm{P}_{30} \mathrm{~K}_{60}$ & 1 & 1 & 30 & 32 & 3 & - & 97 \\
\hline $\mathrm{HIP}_{05}, \mathrm{t} / \mathrm{ha}$ & & & & & & & \\
\hline
\end{tabular}

Notes: ${ }^{*} \odot$ - annuals; $\Theta$ - biennials; $\Upsilon$ - perennials 
The distribution of components by meadow grass stand families of the floodplain, depending on surface improvement measures, is shown in Table 4. Analysis of the results showed that 45 species of meadow plants from 21 families were recorded in the meadow grass stand of the floodplain with different improvement options and different use modes. The following families represented the species that took part in the formation of the meadow grass stand crop: Asteraceae, Araliaceae, Fabaceae, Caryophyllaceae, Polygonaceae, Ranunculaceae,
Poaceae, Apiaceae, Nelumbonaceae, Plantaginaceae, Scrophulariaceae, Rosaceae, Juncaceae, Equisetaceae, Brassicaceae etc. Most of the species, namely 15, belonged to the Poaceae family. the Asteraceae family was the second with 5 types of herbs, the Fabaceae and Rosaceae families were on the third with 3 types of each, and the Scrophulariaceae and Cyperaceae families were the fourth with 2 types of each. The remaining families were represented by one species each.

Table 4. Distribution of components by families of meadow grass stand of the floodplain depending on surface improvement measures, pcs. ( $3^{\text {rd }}$ year of Use 2019)

Haymaking use

\begin{tabular}{|c|c|c|c|c|c|c|c|c|c|}
\hline Families & $\begin{array}{l}\text { Without } \\
\text { fertilizers }\end{array}$ & $P_{30} K_{60}$ & $\mathbf{N}_{60} \mathbf{P}_{30} \mathbf{K}_{60}$ & $\begin{array}{c}\mathrm{N}_{60} \mathrm{P}_{30} \mathrm{~K}_{60}+ \\
\text { seeding of } \\
\text { the Poaceae } \\
\text { mixture }\end{array}$ & $\begin{array}{c}\text { Without } \\
\text { fertilizers }\end{array}$ & $\mathbf{P}_{30} \mathbf{K}_{60}$ & $\begin{array}{l}\mathrm{P}_{30} \mathrm{~K}_{60}+ \\
\text { seeding } \\
\text { Trifolium } \\
\text { repens } \mathrm{L} .\end{array}$ & $\mathrm{N}_{60} \mathrm{P}_{30} \mathrm{~K}_{60}$ & $\begin{array}{l}\text { Total } \\
\text { types }\end{array}$ \\
\hline Asteraceae & 3 & 3 & 5 & 5 & 5 & 5 & 5 & 5 & 5 \\
\hline Araliaceae & 1 & 1 & - & - & 1 & 1 & - & 1 & 1 \\
\hline Blechnaceae & 1 & 1 & - & - & 1 & 1 & - & - & 1 \\
\hline Fabaceae & 2 & 2 & 1 & - & 3 & 3 & 3 & 3 & 3 \\
\hline Caryophyllaceae & 1 & 1 & 1 & - & - & - & - & - & 1 \\
\hline Polygonaceae & 1 & 1 & 1 & 1 & 1 & 1 & 1 & 1 & 1 \\
\hline Lamiaceae & 1 & 1 & - & - & - & - & - & - & 1 \\
\hline Campanulaceae & 1 & 1 & - & - & 1 & 1 & - & 1 & 1 \\
\hline Ranunculaceae & 1 & 1 & 1 & 1 & 1 & 1 & 1 & 1 & 1 \\
\hline Poaceae & 13 & 13 & 11 & 10 & 15 & 15 & 10 & 10 & 15 \\
\hline Apiaceae & 1 & 1 & 1 & 1 & 1 & 1 & 1 & 1 & 1 \\
\hline Nelumbonaceae & 1 & 1 & 1 & 1 & 1 & 1 & 1 & 1 & 1 \\
\hline Rubiaceae & 1 & 1 & - & - & 1 & 1 & - & 1 & 1 \\
\hline Cyperaceae & - & - & - & - & 2 & 2 & - & - & 2 \\
\hline Plantaginaceae & 1 & 1 & 1 & 1 & 1 & 1 & 1 & 1 & 1 \\
\hline Scrophulariaceae & 2 & 2 & 1 & 1 & 2 & 2 & 1 & 1 & 2 \\
\hline Rosaceae & 3 & 3 & 3 & 3 & 3 & 3 & 3 & 3 & 3 \\
\hline Juncaceae & 1 & 1 & 1 & 1 & 1 & 1 & 1 & 1 & 1 \\
\hline Violaceae & - & - & - & - & 1 & 1 & - & - & 1 \\
\hline Equisetaceae & 1 & 1 & 1 & - & 1 & 1 & - & - & 1 \\
\hline $\begin{array}{c}\text { Brassicaceae } \\
\text { (Cruciferae) }\end{array}$ & 1 & 1 & 1 & 1 & 1 & 1 & 1 & 1 & 1 \\
\hline Total families & 19 & 19 & 14 & 11 & 19 & 19 & 12 & 15 & 21 \\
\hline Total types & 37 & 37 & 30 & 26 & 43 & 43 & 29 & 32 & 45 \\
\hline
\end{tabular}

In the Poaceae family, most of the types were for multi-year use on options without fertilizers and against the background of $\mathrm{P}_{30} \mathrm{~K}_{60}$. Among the surface improvement options, the largest number of families (19) was observed for multi-year use on options without fertilizers and against the background of $\mathrm{P}_{30} \mathrm{~K}_{60}$, and the smallest (11-12) - for sowing the mixture of Poaceae herbs on the background of $\mathrm{N}_{60} \mathrm{P}_{30} \mathrm{~K}_{60}$ for haymaking use 
and sowing Trifolium repens $\mathrm{L}$. for multi-year use on the background of $\mathrm{P}_{30} \mathrm{~K}_{60}$.

\section{CONCLUSIONS}

Floodplain meadow phytocenoses are mainly cereals and mixed grasses with a share of wild cereals of $57-58 \%$ (up to 15 of them \% Festuca rubra L. s. str. and $5-6 \%$ of low-value ones in feed terms Calamagrostis arundinaceae (L.) Roth and Deschampsia caespitosa (L.) Beauv.), mixed grasses $-35-38 \%$ and unseeded Fabaceae 5-7\%. When applying a set of measures for surface improvement of cereals and mixed grasses, low productive (within 1.95$2.15 \mathrm{t} / \mathrm{ha}$ of dry weight) floodplain mountain meadowlands, their species composition improved. For making $\mathrm{P}_{30} \mathrm{~K}_{60}$ the content of wild plants increased by $2-5 \%$ Fabaceae, $\mathrm{A} \mathrm{N}_{60} \mathrm{P}_{30} \mathrm{~K}_{60}$ - for $9-10 \%$ of unseeded cereals.
For haymaking use and sowing a mixture of Poaceae with Phleum pratense L. and Festuca pratensis Huds. against the background of making $\mathrm{N}_{60} \mathrm{P}_{30} \mathrm{~K}_{60}$ in the sod in spring, their share increased to $74 \%$, and to $44 \%$ or by $32 \%$ for multi-year use and sowing Trifolium repens $L$. against the background of making $\mathrm{P}_{30} \mathrm{~K}_{60}$ quantity Fabaceae increased.

The highest floral saturation (43 species from 19 families and $93-98 \%$ from perennials) was observed in variants without fertilization and with the introduction of $\mathrm{P}_{30} \mathrm{~K}_{60}$ for multi-year use, which is 4-14 species more compared to haymaking use, or with the introduction of $\mathrm{N}_{60} \mathrm{P}_{30} \mathrm{~K}_{60}$ and/or with sowing the mixture of Poaceae herbs on the background of $\mathrm{N}_{60} \mathrm{P}_{30} \mathrm{~K}_{60}$ for haymaking use, or sowing Trifolium repens $\mathrm{L}$. against the background of $\mathrm{P}_{30} \mathrm{~K}_{60}$ for multipurpose use.

\section{REFERENCES}

[1] Kurhak, V.H., Panasyuk, S.M., Asanishvili, N.M., Slyusar, I.T., Shtakal, M.I., Ptashnik, M.M., Oksymets, O.L., Tsymbal, Ya.S., Kushchuk, M.O., Gavrysh, Ya.V., Kulyk, R.M., \& Kudrya, S.O. (2020). Influence of perennial legumes on the productivity of meadow phytocenoses. Ukrainian Journal of Ecology, 10(6), 310-315. doi: 10.15421/2020_298.

[2] Bohovin, A.V., Sliusar, I.T., \& Tsarenko, M.K. (2005). Herbaceous biogeocenoses, their improvement and rational use. Kyiv: Agrarian Science.

[3] Karbivska, U., Kurgak, V., Gamayunova, V., Butenko, A., Malynka, L., Kovalenko, I., Onychko, V., Masyk, I., Chyrva, A., Zakharchenko, E., Tkachenko, O., \& Pshychenko, O. (2020). Productivity and quality of diverse ripe cereal grass fodder depends on the methods of soil cultivation. Acta Agrobotanica, 73(3), 1-11. doi: 10.5586/aa.7334.

[4] Demydas, G.I., \& Prorochenko, S.S. (2018). Botanical structure and features of forming lucerne-cereal herbage depending on fertilizing in environments of Right-Bank Forest-Steppe. Myronivskyi Herald, 7, 123-134.

[5] Kovtun, K.P., Veklenko, Yu.A., \& Yashchuk, V.A. (2020). Formation of phytocenosis and productivity of sainfoincereal grass mixtures depending on the methods of sowing and spatial distribution of species in the conditions of the right-bank Forest-Steppe. Feed and Feed Production, 89, 112-120. doi: 10.31073/kormovyrobnytstvo202089-11.

[6] Kotyash, U., Bugryn, L., Panakhyd, H., \& Pukalo, D. (2019). Features formation of different age meadowy swards depending on surface improvement. Foothill and Mountain Agriculture and Stockbreeding, 66, 117-129.

[7] Moiseenko, V. (2011). Scientific grounds for the ways of improving fodder productivity and perennial grass stand productive longevity. Bulletin of ZhNAEU, 1(28), 35-37.

[8] Bohovin, A.V., Travleyev, A.P., Belova, N.A., \& Dudnyk, S.V. (2003). Ecological analysis of vegetation of natural biogeocenoses (physiognomic and floristic-individualistic aspectsof analysis in ecology). Ecology and Noospherology, 13(1-2), 4-11.

[9] Mashchak, Ya.I., Sloboda, Ya.Ya., Sloboda, O.M., \& Vyhovsky, I.V. (2012). Agrobiological substantiation of improvement of productivity of natural forage lands. Foothill and Mountain Agriculture and Stockbreeding, 54(1), 40-45.

[10] Petrychenko, V.F., Korniichuk, O.V., \& Veklenko, Yu.A. (2018). Sustainable development of grassland forage production in conditions of climate change. Bulletin of Agricultural Science, 96(6), 25-32.

[11] Dzyubaylo, A., Martsinko, T., \& Holovchuk, M. (2020). Formation of legume-cereal grass mixtures depending on fertilization. Foothill and Mountain Agriculture and Stockbreeding, 67(1), 39-53.

[12] Bugryn, L., Kotyash, U., Smetana, S., Bugryn, O., \& Pukalo, D. (2020). Productive potential of meadow phytocenoses as a source of grass forages for cattle farming in the Carpathian region. Foothill and Mountain Agriculture and Stockbreeding, 67(1), 9-24.

[13] Panakhyd, H., Konyk, H., \& Kotyash, U. (2019). The contents of organic matter in the forage of meadow with different grasses agrophytocenosis for long-term use. Foothill and Mountain Agriculture and Stockbreeding, 65, 103-114.

[14] Kvitko, H.P., \& Hetman, N.Ya. (2003). Nitrogen-fixing capacity and supply of soil with nitrogen depending on the years of life of alfalfa sown in the Forest-Steppe. Feed and Feed Production, 51, 54-57.

[15] Parente, G., \& Bovolenta, S. (2012). The role of grassland in rural tourism and recreation in Europe. In Grassland - $a$ European Resource. Proceedings of the 24th EGF General Meeting. (pp. 733-743). Lublin.

[16] Babich, A.O. (Ed.). (1994). Methods of conducting experiments on feed production. Vinnytsia.

[17] DSTU 4687:2007. Natural forage lands. Method of botanical survey of grasses. (2008). Kyiv: Derzhspozhyvstandart Ukrainy. 
[18] Dobrochaeva, D.N., Kotov, M.I., \& Prokudin, Yu.H. (1987). Determinant of higher plants of Ukraine. Kyiv: Naukova dumka.

[19] Bogovin, A.V. (2011). Types of categories of biodiversity in the conditions of anthropogenic transformation of the ecological systems. Ecology and Noospherology, 22(3-4), 73-83.

[20] Bogovin, A.V. (2008). Improving the efficiency of the use of meadows for global warming. Collection of scientific works of the National Scientific Center "Institute of Agriculture of NAAS", SI, 33-41.

\title{
Динаміка видового складу фітоценозів заплавних гірських луків Карпат за поверхневого їх поліпшення
}

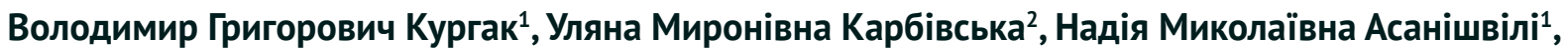 Сергій Миколайович Слюсар ${ }^{1}$, Михайло Михайлович Пташнік ${ }^{1}$}

\author{
${ }^{1}$ ННЦ «Інститут землеробства НААН» \\ 08162, вул. Машинобудівників, 2-б, смт Чабани, Київська обл., Україна \\ 2Прикарпатський національний університет ім. Василя Стефаника \\ 76018, вул. Шевченка, 57, м. Івано-Франківськ, Україна
}

\begin{abstract}
Анотація. Проведеними дослідженнями різних авторів розроблено ряд заходів поверхневого поліпшення лучних угідь у різних ґрунтово-кліматичних умовах. Однак досліджень стосовно вивчення впливу таких заходів поверхневого поліпшення як застосування органічних і мінеральних добрив та підсівання злакових і бобових багаторічних трав у дернину на динаміку видового складу заплавних гірських луків Карпат ще не проводилось, що підтверджує актуальність даного дослідження. У статті наведено результати трирічних досліджень, проведених впродовж 2017-2019 рр. у селянському господарстві Мартищука В.Ф. (Верховинський район Івано-Франківської області) з вивчення особливостей трансформації видового складу природних фітоценозів заплавних луків р. Чорний Черемош гірсько-лісового поясу Карпат під дією поверхневого їх поліпшення із застосуванням органічних і мінеральних добрив та підсівання злакової суміші за сінокісного використання і Trifolium repens L. - за багатоукісного використання. Встановлено, що заплавні лучні фітоценози $\epsilon$ переважно злаково-різнотравними з часткою дикорослих злаків 57-58 \% (з них до 15 \% Festuca rubra L. s. str. i по 5-6 \% малоцінних у кормовому відношенні Calamagrostis arundinaceae (L.) Roth та Deschampsia caespitosa (L.) Beauv.), різнотрав'я - 35-38 \% та несіяних Fabaceae 5-7 \%. За застосування комплексу заходів поверхневого поліпшення злаково-різнотравних, низькопродуктивних (в межах 1,95-2,15 т/га сухої маси) заплавних гірських лучних угідь покращувався їх видовий склад. За внесення $\mathrm{P}_{30} \mathrm{~K}_{60}$ на 2-5 \% збільшувався вміст дикорослих Fabaceae, а $\mathrm{N}_{60} \mathrm{P}_{30} \mathrm{~K}_{60}$ - на 9-10 \% несіяних Роасеае. За сінокісного використання за підсівання навесні в дернину суміші Poaceae 3 Phleum pratense L. і Festuca pratensis Huds. на фоні внесення $\mathrm{N}_{60} \mathrm{P}_{30} \mathrm{~K}_{60}$ частка їх збільшилася до 74 \%, а за багатоукісного використання й за підсівання Trifolium repens L. на фоні внесення $\mathrm{P}_{30} \mathrm{~K}_{60}$ кількість Fabaceae збільшилася до 44 \% або на 32 \%. Найбільша флористична насиченість (43 види з 19 родини та на 93-98 \% з багаторічників) спостерігалася у варіантах без внесення добрив та за внесення $\mathrm{P}_{30} \mathrm{~K}_{60}$ за багатоукісного використання, що на 4-14 видів більше у порівнянні з сінокісним використанням, або з внесенням $\mathrm{N}_{60} \mathrm{P}_{30} \mathrm{~K}_{60}$ та або з підсіванням суміші злакових трав на фоні $\mathrm{N}_{60} \mathrm{P}_{30} \mathrm{~K}_{60}$ за сінокісного використання, або підсівання Trifolium repens L. на фоні $\mathrm{P}_{30} \mathrm{~K}_{60}$ за багатоукісного використання
\end{abstract}

Ключові слова: бобові, злаки, видовий склад, лучний фітоценоз, різнотрав'я, флористична насиченість 